\title{
ISLAM MEMANDANG HAK ASASI PENDIDIKAN
}

\section{Imam Machali}

Fakultas Tarbiyah dan Keguruan UIN Sunan Kalijaga Yogyakarta

Jl. Marsda Adi Sucipto Yogyakarta 55281

E-mail: imam_machali@yahoo.co.id

\begin{abstract}
ABSTRAK
Pemenuhan terhadap hak atas pendidikan di Indonesia sebagai amanat luhur konstitusi menghadapi banyak masalah. Masalah-masalah tersebut meliputi masalah legislasi dan kebijakan, anggaran pendidikan, pemerataan dan akses pendidikan yang mencakup kesetaraan gender dalam memperoleh pendidikan serta akses pendidikan di wilayah konflik, perbatasan dan terpencil. Masalah legislasi terkait dengan belum sepenuhnya selaras antara undang-undang dan kebijakan pendidikan nasional dengan cita-cita luhur kemerdekaan dan konstitusi UUD 1945, dan antara instrumen HAM nasional dengan standar konvensi internasional, sehingga pembangunan di bidang pendidikan belum berbasis hak-hak asasi manusia. Masalah anggaran pendidikan berhubungan dengan komitmen pemerintah dalam mengalokasikan anggaran pendidikan berdasarkan undang-undang. Masalah pemerataan dan perluasan akses pendidikan mencakup kemampuan daya tampung satuan pendidikan dan pemberian kesempatan yang sama bagi semua calon peserta didik dari berbagai golongan masyarakat. Berbagai masalah tersebut berdampak pada belum terpenuhinya hak asasi warga Negara Indonesia dalam memperoleh pendidikan yang layak, sebagaimana diamanatkan dalam Pembukaan Undang-Undang Dasar RI 1945.
\end{abstract}

Kata Kunci: HAM, Islam, Pendidikan

\begin{abstract}
Fulfilling the education right in Indonesia as stated in the constitution faces a lot of problems. The problems include lagislation and policy, budgeting of education, fair distribution and easy access to education covering gender equality in getting and accessing education in area of conflict, boundaries, and remoted area. Problem of legislation related to law and national education policy and noble ideal of independence and the Constitution 1945, Instrument and National and International Standard of Human Right which are not in line yet, results in the condition that the education development is not based on the human right. The education budgeting relates to government commitment to allocate the amount based on the law, fair distribution and wide access to education covering the unit capacity and providing equal opportunities to all learners from different social, economic background, place of living, intelectual capacity, physical condition and gender. Those problems lead to unfulfilled education right as stated independece goals.
\end{abstract}

Key words: Human Right, Islam, Education 


\section{PENDAHULUAN}

Pasal 26 hasil Deklarasi Universal Hak Asasi Manusia (Universal Declaration of Human Right) tahun 1948 menyebutkan: "Everyone has the right to education. Education shall be free, at least in the elementary and fundamental stages. Elementary education shall be compulsory. Technical and professional education shall be made generally available and higher education shall be equally accessible to all on the basis of merit".

Berdasarkan kutipan di atas, pada dasarnya semua orang berhak mendapatkan pendidikan yang berkualitas terutama pada level pendidikan dasar. Hak asasi pendidikan adalah hak sipil dan politis yang harus dilindungi, dipenuhi dan dihormati oleh negara sebagaimana tercantum dalam International Covenant on Civil and Political Rights tahun 1966 pasal 18 ayat 4. Pasal tersebut menyatakan: "The States Parties to the present Covenant undertake to have respect for the liberty of parents and, when applicable, legal guardians to ensure the religious and moral education of their children in conformity with their own convictions". Berdasarkan kutipan tersebut, negara juga wajib melindungi dan menghargai kebebasan orang tua dalam mendidik agama dan akhlak anak sesuai dengan kepercayaan dan keyakinannya masing-masing.

Selain dalam kovenan di atas, hak asasi pendidikan anak juga dijamin dalam kesamaan dan kebebasan memperolehnya dalam Konvensi Hak Asasi Anak 1989 (Convention on The Rights of The Child). Pasal 28 ayat 1 dan 3 hasil konvensi tersebut antara lain menyebutkan: "States Parties recognize the right of the child to education, and with a view to achieving this right progressively and on the basis of equal opportunity, they shall, in particular: (a) Make primary education compulsory and available free to all...".

Ayat 3, dari hasil konvensi tersebut juga menyatakan, "States Parties shall promote and encourage international cooperation in matters relating to education, in particular with a view to contributing to the elimination of ignorance and illiteracy throughout the world and facilitating access to scientific and technical knowledge and modern teaching methods. In this regard, particular account shall be taken of the needs of developing countries". Negara harus memfasilitasi warga negaranya dalam memperoleh ilmu pengatahuan dan pendidikan yang modern dan berkualitas agar kelak dapat memberikan kontribusi dalam membangun negaranya.

Indonesia sebagai negara berdaulat dan bagian dari anggota Perserikatan Bangsa-Bangsa (PBB) mengemban tanggung jawab moral dan hukum untuk menjunjung tinggi dan melaksanakan hasil Deklarasi Universal tentang Hak Asasi Manusia yang ditetapkan oleh Perserikatan Bangsa-Bangsa. Berbagai instrumen internasional mengenai hak asasi manusia telah diterima dengan tangan terbuka oleh Negara Republik Indonesia. Untuk itu, Indonesia melalui parlemen atau pemerintah telah meratifikasi (mengesahkan/menyetujui) berbagai perjanjian/kesepakatan hukum/konvensi dan kovenan internasional dalam sebuah sistem hukum negara. Di antara beberapa upaya tersebut, yaitu; Konvensi tentang Penghapusan Segala Bentuk Diskriminasi terhadap Perempuan Convention on the Elmination of Discrimination againts Women, telah 
diratifikasi (disahkan) dengan UU Nomor 7 Tahun 1984; Konvensi Hak Anak Convention on the Rights of the Child telah disahkan dengan Kepres 36 Tahun 1990; Kovenan Internasional Hak Ekonomi, Sosial, dan Budaya (Hak Ekosob, ICESCR) telah disahkan dengan UU Nomor 11 tahun 2005 tentang Pengesahan International Covenant on Economic, Social and Cultural Rights (Kovenan Internasional Tentang Hak-Hak Ekonomi, Sosial dan Budaya); dan Kovenan Internasional Hak Sipil dan Politik (Hak Sipol, ICCPR) disahkan oleh UU Nomor 12 Tahun 2005 tentang Pengesahan International Covenant on Civil and Political Rights (Kovenan Internasional Tentang Hak-Hak Sipil dan Politik).

Berbagai pengesahan/persetujuan (ratifikasi) terhadap sejumlah perjanjian internasional di atas menimbulkan konsekuensi, bahwa pemerintah Indonesia dituntut untuk melaksanakan hak-hak asasi warga negaranya. Bagaimanapun juga Negara Indonesia telah mengikatkan diri secara hukum terhadapnya. Pemerintah bukan hanya berkewajiban untuk mengadopsi perjanjian yang telah diratifikasi ini ke dalam perundang-undangan, baik yang dirancang maupun yang telah diberlakukan sebagai undang-undang, namun pemerintah memiliki kewajiban mengikat yakni mengambil berbagai langkah nyata untuk menghormati (to respect), melindungi (to protect) dan memenuhi (to fullfil) hak-hak manusia ${ }^{1}$.

Sesungguhnya berbagai instrumen internasional di atas sejalan dengan semangat Pancasila dan Undang-Undang Dasar Negara Republik Indonesia Tahun 1945 yang menyebutkan bahwa Negara Republik Indonesia adalah negara hukum yang menjunjung tinggi harkat dan martabat manusia dan menjamin persamaan kedudukan semua warga negara di dalam hukum. Bangsa Indonesia juga secara terus-menerus memajukan dan melindungi hak asasi manusia dalam kehidupan berbangsa dan bernegara. Dalam Pembukaan UUD 1945 ditegaskan bahwa Negara Indonesia bertekad melindungi segenap bangsa Indonesia dan seluruh tumpah darah Indonesia, memajukan kesejahteraan umum, mencerdaskan kehidupan bangsa, dan ikut melaksanakan ketertiban dunia yang berdasarkan kemerdekaan, perdamaian abadi dan keadilan sosial.

Amanat pembukaan undang-undang di atas yakni mencerdaskan kehidupan bangsa, kemudian dijelmakan menjadi kewajiban konstitusi sebagaimana termaktub dalam UUD 1945 pasal 31 (1) bahwa setiap warga negara berhak mendapat pendidikan; (2) wajib mengikuti pendidikan dasar dan pemerintah wajib membiayainya; (3) pemerintah mengusahakan dan menyelenggarakan satu sistem pendidikan nasional, yang bertujuan meningkatkan keimanan dan ketakwaan serta akhlak mulia dalam rangka mencerdaskan kehidupan bangsa, yang diatur dengan undang-undang; (4) negara memprioritaskan anggaran pendidikan sekurang-kurangnya dua puluh persen dari anggaran pendapatan dan belanja negara serta dari anggaran pendapatan dan belanja daerah untuk memenuhi kebutuhan penyelenggaraan pendidikan nasional, dan (5) pemerintah memajukan ilmu pengetahuan dan teknologi dengan menunjang tinggi nilai-nilai agama dan persatuan bangsa untuk kemajuan peradaban serta kesejahteraan umat manusia. Akan tetapi, cita-cita 
luhur dan ideal tersebut di atas masih sangat jauh dengan kenyataan yang terjadi. Cita-cita keadilan sosial bagi seluruh rakyat Indonesia, yang merupakan sila kelima Pancasila hanya sebatas cita-cita mulia. Kenyataan menunjukkan bahwa di Indonesia, angka putus sekolah masih tinggi. Warga masyarakat masih banyak yang belum atau "tidak" dapat menikmati layanan pendidikan. Biaya pendidikan sangat mahal. Anggaran pendidikan masih kurang. Akses terhadap sumber belajar masih sulit. Sarana dan pra-sarana pendidikan masih juga belum tersedia dengan layak. Layanan pendidikan di daerah perbatasan dan wilayah konflik masih sulit diperoleh. Semua itu adalah cermin bahwa harapan dan idealisme amanat Undang-Undang Dasar untuk melaksanakan hak asasi pendidikan masih jauh dari komitmen dan realitas yang dialami oleh rakyat.

Tulisan ini bertujuan menggambarkan bahwa hak dasar warga negara Indonesia dalam mendapatkan pendidikan masih mengalami banyak kendala. Islam sebagai agama yang mayoritas dianut oleh warga Indonesia dituntut berperan lebih aktif dalam memberikan solusi atas kenyataan di atas. Tulisan ini berusaha memberikan landasan teologis terutama menyangkut beberapa argumen tentang hak mendapatkan pendidikan sehingga pemerintah lebih amanah dalam menyusun dan melaksanakan kebijakannya. Masyarakat biasanya lebih percaya pada kebijakan yang bernuansa religius dan Islami. Data dalam tulisan ini dianalisis berdasarkan teori pendidikan Islam.

\section{PEMBAHASAN}

\section{Pendidikan Sebagai Hak Warga Negara}

Pendidikan sebagai hak asasi manusia di Indonesia dijamin oleh konstitusi dan undang-undang. Salah satu tujuan dan tugas dibentuknya Negara Indonesia diantaranya adalah untuk mencerdaskan kehidupan bangsa sebagaimana diamanatkan dalam pembukaan UUD 1945.

Amanat UUD 1945 tentang mencerdaskan kehidupan bangsa berarti negara mempunyai kewajiban untuk mengusahakan, memberikan layanan dan fasilitas yang cukup kepada warga negara dalam rangka mencerdaskan warga negaranya. Usaha tersebut dapat tercapai dengan cara memberikan layanan pendidikan yang memadai. Amanat "mencerdaskan kehidupan bangsa" bukanlah konsepsi biologis-genetik yang diwariskan akan tetapi merupakan konsepsi budaya dan pembudayaan yang diperoleh melalui sebuah proses pendidikan. Para ahli pendidikan Indonesia secara konseptual menyepakati bahwa mencerdaskan kehidupan bangsa harus dilakukan melalui proses pendidikan sebab kecerdasan tidak genetically fixed, tetapi dapat diajarkan dan dipelajari. Kedudukan dan fungsi pendidikan menjadi sarana dalam rangka mewujudkan amanat "mencerdaskan kehidupan bangsa", maka memberikan layanan pendidikan terhadap warga negara menjadi wajib dilakukan oleh negara. Dengan kata lain, memperoleh pendidikan merupakan hak asasi bagi warga negara, sedangkan memberikan layanan pendidikan menjadi kewajiban negara kepada warganya. 
Hak asasi ini mempunyai pengertian seperangkat hak yang melekat pada hakikat dan keberadaan manusia sebagai makhluk Tuhan Yang Maha Kuasa dan merupakan anugerah-Nya yang wajib dihormati, dijunjung tinggi dan dilindungi oleh negara, hukum, pemerintah dan setiap orang, demi kehormatan serta perlindungan harkat dan martabat manusia. ${ }^{2}$

Pendidikan sebagai Hak Asasi Manusia selanjutnya dituangkan dalam UUD 1945 pasal 31 hasil amandemen yaitu, "Setiap warga Negara berhak mendapatkan pendidikan", "Setiap warga negara wajib mengikuti pendidikan dasar dan pemerintah wajib membiayainya".

Pemenuhan hak pendidikan juga dinyatakan dalam UU Nomor 39 Tahun 1999 tentang Hak Asasi Manusia. Pasal 12 menyebutkan bahwa:

"Setiap orang berhak atas perlindungan bagi pengembangan pribadinya, untuk memperoleh pendidikan, mencerdaskan dirinya, dan meningkatkan kualitas hidupnya agar menjadi manusia yang beriman, bertaqwa, bertanggungjawab, berakhlak mulia, bahagia, dan sejahtera sesuai dengan hak asasi manusia".

Undang-Undang Sistem Pendidikan Nasional Nomor 20 Tahun 2003 pada bab 5, tentang Hak dan Kewajiban Warga Negara, Orang Tua, Masyarakat, dan Pemerintah, pasal 5 menyebutkan bahwa; (1) Setiap warga negara mempunyai hak yang sama untuk memperoleh pendidikan yang bermutu; (2) Warga negara yang memiliki kelainan fisik, emosional, mental, intelektual, dan/atau sosial berhak memperoleh pendidikan khusus; (3) Warga negara di daerah terpencil atau terbelakang serta masyarakat adat yang terpencil berhak memperoleh pendidikan layanan khusus; (4) Warga negara yang memiliki potensi kecerdasan dan bakat istimewa berhak memperoleh pendidikan khusus; (5) Setiap warga negara berhak mendapat kesempatan meningkatkan pendidikan sepanjang hayat.

Undang-undang di atas menyebutkan bahwa hak atas pendidikan juga merupakan hak sipil dan politik yang harus dilindungi, dipenuhi, dan hormati oleh negara. Kovenan Internasional Hak Sipil dan Politik (Hak Sipol, ICCPR) yang telah diratifiksi melalui UU Nomor 12 Tahun 2005 tentang Pengesahan International Covenant on Civil and Political Rights (Kovenan Internasional Tentang Hak-Hak Sipil dan Politik) menyebutkan bahwa "Negara pihak dalam kovenan ini berjanji untuk menghormati kebebasan orang tua dan apabila diakui, wali hukum yang sah, untuk memastikan bahwa pendidikan agama dan moral bagi anak-anak mereka sesuai dengan keyakinan mereka sendiri"3.

Konvensi Hak Anak Convention on the Rights of the Child yang telah diratifikasi dengan Kepres 36 Tahun 1990 juga menegaskan bahwa "negaranegara pihak mengakui hak anak atas pendidikan, dan dengan tujuan mencapai hak ini secara progresif dan berdasarkan kesempatan yang sama, mereka harus, terutama: (a) Membuat pendidikan dasar diwajibkan dan terbuka bagi semua anak....". 4 
Berbagai dasar perundang-undangan yang menjamin hak atas pendidikan tersebut kemudian dijadikan pijakan dan landasan dalam melaksanakan berbagai program pendidikan di Indonesia. Kementerian Pendidikan dan Kebudayaan Nasional sebagai penanggungjawab pelaksanaan sistem pendidikan nasional kemudian menyusun rencana strategis pendidikan nasional. Rencana strategis ini didasarkan pada tujuan dan fungsi pendidikan nasional yang menyatakan bahwa "Pendidikan nasional berfungsi mengembangkan kemampuan dan membentuk watak serta peradaban bangsa yang bermartabat dalam rangka mencerdaskan kehidupan bangsa. Pendidikan nasional juga bertujuan untuk mengembangkan potensi peserta didik agar menjadi manusia yang beriman dan bertaqwa kepada Tuhan Yang Maha Esa, berakhlak mulia, sehat, berilmu, cakap, kreatif, mandiri, dan menjadi warga negara yang demokratis serta bertanggung jawab".5 Untuk hal tersebut Kemendikbud merumuskan visi, dan misi yang harus dijalankan oleh semua aparat terkait dengan kementerian tersebut.

Visi dan misi pendidikan nasional berangkat dari paradigma pembangunan pendidikan nasional yaitu "membangun manusia Indonesia seutuhnya, yang berfungsi sebagai subyek yang memiliki kapasitas untuk mengaktualisasikan potensi dan dimensi kemanusiaan secara optimal". Dimensi kemanusiaan ini mencakup tiga hal paling mendasar, yaitu (1) afektif yang tercermin pada kualitas keimanan, ketaqwaan, akhlak mulia termasuk budi pekerti luhur serta kepribadian unggul, dan kompetensi estetis; (2) kognitif yang tercermin pada kapasitas pikir dan daya intelektualitas untuk menggali dan mengembangkan serta menguasai ilmu pengetahuan dan teknologi; dan (3) psikomotorik yang tercermin pada kemampuan mengembangkan keterampilan teknis, kecakapan praktis, dan kompetensi kinestetis.

Berdasarkan paradigma pendidikan nasional, visi pendidikan nasional dirumuskan. Visi tersebut adalah "Terwujudnya sistem pendidikan sebagai pranata sosial yang kuat dan berwibawa untuk memberdayakan semua warga negara Indonesia untuk berkembang menjadi manusia yang berkualitas sehingga mampu dan proaktif menjawab tantangan zaman yang selalu berubah". Dalam rangka hal tersebut Kemendikbud mencanangkan bawa pada tahun 2025 harus menghasilkan "Insan Indonesia Cerdas dan Kompetitif' (Insan Kamil/Insan Paripurna). Insan Indonesia cerdas adalah insan yang cerdas spiritual, cerdas emosional, cerdas sosial, cerdas intelektual, dan cerdas kinestetis. Cerdas spiritual berarti beraktualisasi diri melalui olah hati/kalbu untuk menumbuhkan dan memperkuat keimanan, ketaqwaan dan akhlak mulia termasuk budi pekerti luhur dan kepribadian unggul. Cerdas emosional dan sosial berarti beraktualisasi diri melalui olah rasa untuk meningkatkan sensitivitas dan apresiasi akan kehalusan dan keindahan seni dan budaya, serta kompetensi untuk mengekspresikannya. Beraktualisasi diri melalui interaksi sosial yang: membina dan memupuk hubungan timbal balik; demokratis; empatik dan simpatik; menjunjung tinggi hak asasi manusia; ceria dan percaya diri; menghargai kebhinekaan dalam 
bermasyarakat dan bernegara; serta berwawasan kebangsaan dengan kesadaran akan hak dan kewajiban warga negara. Cerdas intelektual berarti beraktualisasi diri melalui olah pikir untuk memperoleh kompetensi dan kemandirian dalam ilmu pengetahuan dan teknologi, aktualisasi insan intelektual yang kritis, kreatif dan imajinatif. Cerdas kinestetis berarti beraktualisasi diri melalui olah raga untuk mewujudkan insan yang sehat, bugar, berdaya-tahan, sigap, terampil, dan trengginas (aktualisasi insan adiraga).

Misi pendidikan nasional adalah (1) Mengupayakan perluasan dan pemerataan kesempatan memperoleh pendidikan yang bermutu bagi seluruh rakyat Indonesia; (2) Membantu dan memfasilitasi pengembangan potensi anak bangsa secara utuh sejak usia dini sampai akhir hayat dalam rangka mewujudkan masyarakat belajar; (3) Meningkatkan kesiapan masukan dan kualitas proses pendidikan untuk mengoptimalkan pembentukan kepribadian yang bermoral; (4) Meningkatkan profesionalitas dan akuntabilitas lembaga pendidikan sebagai pusat pembudayaan ilmu pengetahuan, keterampilan, pengalaman, sikap, dan nilai berdasarkan standar nasional dan global; dan (5) Memberdayakan peran serta masyarakat dalam penyelenggaraan pendidikan berdasarkan prinsip otonomi dalam konteks Negara Kesatuan RI.

\section{Masalah Pemenuhan Hak Asasi Pendidikan}

Pemenuhan terhadap hak atas pendidikan di Indonesia sebagai amanat luhur konstitusi menghadapi berbagai problem. Masalah-masalah tersebut meliputi masalah legislasi dan kebijakan, masalah anggaran pendidikan, masalah pemerataan dan masalah akses pendidikan yang mencakup kesetaraan gender dalam memperoleh pendidikan dan akses pendidikan di wilayah konflik, perbatasan dan terpencil. Berikut ini akan diulas beberapa masalah tersebut dan alternatif pemecahan yang ditawarkan.

\section{Masalah Legislasi dan Kebijakan}

Masalah mendasar dalam pemenuhan hak atas pendidikan di Indonesia adalah masalah legislasi dan kebijakan. Antara Undang-Undang (kebijakan) Pendidikan Nasional dengan cita-cita luhur kemerdekaan dan konstitusi UUD 1945, antara instrumen-instrumen dan standar HAM nasional dengan internasional ternyata belum selaras sehingga pembangunan di bidang pendidikan belum berbasis atas hak asasi manusia.

Kebijakan pembangunan pendidikan nasional yang berbasis pada hak asasi manusia menghendaki konsisten dengan prinsip, instrumen dan standar hak pendidikan internasional yaitu harus diarahkan pada perkembangan kepribadian manusia seutuhnya, kesadaran akan harga dirinya, dan memperkuat penghormatan atas hak-hak asasi dan kebebasan manusia yang mendasar. Mereka selanjutnya setuju bahwa pendidikan harus memungkinkan semua orang untuk berpartisipasi secara efektif dalam suatu masyarakat yang bebas, meningkatkan rasa pengertian, toleransi serta persahabatan antar semua bangsa dan semua kelompok, ras, etnis atau agama, dan lebih memajukan serta 
memelihara perdamaian dunia. Prinsip lain dari ayat 2 dalam Kovenan ini mengakui bahwa untuk mengupayakan hak tersebut secara penuh, pemerintah yang bersangkutan harus betul-betul melaksanakan;

a. Pendidikan dasar yang diwajibkan dan gratis bagi semua orang;

b. Pendidikan lanjutan dalam berbagai bentuknya, termasuk pendidikan teknik dan kejuruan tingkat lanjutan pada umumnya, harus tersedia dan terbuka bagi semua orang dengan segala cara yang layak, dan khususnya melalui pengadaan pendidikan cuma-cuma secara bertahap;

c. Pendidikan tinggi juga harus tersedia bagi semua orang secara merata atas dasar kemampuan, dengan segala cara yang layak, khususnya melalui pengadaan pendidikan cuma-cuma secara bertahap;

d. Pendidikan mendasar harus sedapat mungkin didorong atau ditingkatkan bagi orang-orang yang belum mendapatkan atau belum menyelesaikan pendidikan dasar mereka;

e. Pengembangan suatu sistem sekolah pada semua tingkatan harus secara aktif diupayakan, suatu sistem beasiswa yang memadai harus dibentuk dan kondisi-kondisi materil staf pengajar harus terus-menerus diperbaiki.

Praktik pemenuhan hak atas pendidikan di Indonesia tidak hanya dibebankan pada pemerintah pusat, akan tetapi juga menjadi kewenangan pemerintah daerah (provinsi), dan kabupaten/kota 6 . Hal ini sebagimana diatur dalam Undang-Undang Nomor 32 Tahun 2004 tentang pemerintah daerah pasal 13 menyebutkan bahwa "(1) Urusan wajib yang menjadi kewenangan pemerintahan daerah provinsi merupakan urusan dalam skala provinsi yang meliputi:

a. Perencanaan dan pengendalian pembangunan;

b. Perencanaan, pemanfaatan, dan pengawasan tata ruang;

c. Penyelenggaraan ketertiban umum dan ketenteraman masyarakat;

d. Penyediaan sarana dan prasarana umum;

e. Penanganan bidang kesehatan;

f. Penyelenggaraan pendidikan dan alokasi sumber daya manusia potensial;

g. Penanggulangan masalah sosial lintas kabupaten/kota;

h. Pelayanan bidang ketenagakerjaan lintas kabupaten/kota;

i. Fasilitasi pengembangan koperasi, usaha kecil, dan menengah termasuk lintas kabupaten/kota;

j. Pengendalian lingkungan hidup;

k. Pelayanan pertanahan termasuk lintas kabupaten/kota;

1. Pelayanan kependudukan dan catatan sipil;

m. Pelayanan administrasi umum pemerintahan;

n. Pelayanan administrasi penanaman modal termasuk lintas kabupaten/ kota; 
o. Penyelenggaraan pelayanan dasar lainnya yang belum dapat dilaksanakan oleh kabupaten/kota; dan

p. Urusan wajib lainnya yang diamanatkan oleh peraturan perundangundangan.

Berdasarkan kutipan di atas, untuk mewujudkan amanat undang-undang, setiap daerah seharusnya mengeluarkan peraturan daerah tentang pendidikan yang di dalamnya secara khusus mengatur tentang anggaran pendidikan. Hal ini dimaksudkan sebagai jaminan keterlayanan secara baik semua warga negara mendapatkan hak atas pendidikan.

Dalam rangka melihat ada atau tidaknya pelanggaran HAM dalam bidang pendidikan dari segi legislasi dan kebijakan, maka ada dua panduan yang dapat dijadikan acuan, yaitu prinsip-prinsip Limburg (Limburg Principles) dan panduan Mastricht (Maastricht Guidelines). Panduan Maastricht mengindikasikan bahwa semua pelanggaran dapat terjadi melalui act of commission atau act of omission. Dalam konteks pemenuhan hak atas pendidikan bagi warga negera Indonesia, hendaknya general commitment Nomor 13 tentang hak atas pendidikan. Hal ini dapat diartikan sebagai suatu alat desak terhadap negara bahwa negara berkewajiban memperbaharui legislasinya berdasarkan standar hak asasi manusia nasional maupun internasional.

\section{Masalah Anggaran Pendidikan}

Pemenuhan hak mendapatkan pendidikan bagi seluruh warga negara tanpa diskriminasi sangat terkait dengan komitmen alokasi anggaran untuk sektor pendidikan. Sejarah mencatat bahwa alokasi anggaran pendidikan sebelum amandeman UUD 1945 dan UUSPN nomor 20 tahun 2003 tidak secara jelas disebutkan besaran anggarannya. Karenanya, sektor pendidikan mendapatkan alokasi anggaran paling kecil dibanding dengan sektor lain. Bahkan jika dibandingkan dengan negara-negara lain, Indonesia adalah negara yang mengalokasikan anggaran pendidikan paling rendah. ${ }^{8}$ Saat itu, komitmen pemerintah untuk memenuhi cita-cita konstitusi "mencerdaskan kehidupan bangsa" sempat dipertanyakan.

Besar kecilnya anggaran pendidikan suatu negara berpengaruh terhadap kinerja dan pencapaian pemenuhan hak atas pendidikan bagi warga negaranya. Tingginya angaran pendidikan akan meningkatkan kinerja dan ketercapaian hak atas pendidikan. Sebaliknya, rendahnya alokasi anggaran pendidikan berakibat pada buruknya kinerja dan terabaikannya hak semua warga negara memperoleh pendidikan.

UUD 1945 hasil amandemen pasal 31 ayat 4 mengamanatkan bahwa "Negara memprioritaskan anggaran pendidikan sekurang-kurangnya dua puluh persen dari anggaran pendapatan dan belanja negara serta dari aggaran pendapatan dan belanja daerah untuk memenuhi kebutuhan penyelenggaraan pendidikan nasional". Undang-Undang Sistem Pendidikan Nasional nomor 20 tahun 2003 pasal 49 menyebutkan bahwa "Dana pendidikan selain gaji pendidik 
dan biaya pendidikan kedinasan dialokasikan minimal 20\% dari Anggaran Pendapatan dan Belanja Negara (APBN) pada sektor pendidikan dan minimal 20\% dari Anggaran Pendapatan dan Belanja Daerah (APBD)".

Undang-undang di atas secara jelas menyebutkan sekurang-kurangnya dua puluh persen untuk anggaran pendidikan selain gaji pendidik dan biaya pendidikan kedinasan. Anggaran untuk sektor pendidikan dari APBN memang dari tahun ke tahun terus naik dan mencapai 20\%, akan tetapi peruntukkan dan penggunaannya bukan hanya untuk keperluan praksis pendidikan saja, namun masih termasuk biaya kedinasan dan lain-lain. ${ }^{2}$ Sehingga realisasi dari penggunaan dana menjadi tidak efektif dan efisien. Berikut adalah perbandingan kenaikan anggaran pendidikan dapat dilihat pada tabel berikut:

Tabel 1. Perbandingan Kenaikan Anggaran Pendidikan

\begin{tabular}{|c|c|c|}
\hline APBN & ALOKASI & RASIO \\
\hline $\mathbf{2 0 0 5}$ & 33,40 triliun & $8,1 \%$ \\
\hline $\mathbf{2 0 0 6}$ & 44,11 triliun & $10,1 \%$ \\
\hline $\mathbf{2 0 0 7}$ & 53,07 triliun & $10,5 \%$ \\
\hline $\mathbf{2 0 0 8}$ & 158,52 triliun & $18,5 \%$ \\
\hline $\mathbf{2 0 0 9}$ & 207,41 triliun & $20,0 \%$ \\
\hline $\mathbf{2 0 1 0}$ & 209,54 triliun & $20,0 \%$ \\
\hline $\mathbf{2 0 1 1}$ & 266,9 triliun, & $20,2 \%$ \\
\hline
\end{tabular}

Diolah dari berbagai sumber

Berdasarkan tabel di atas, tanggung jawab pemenuhan hak atas pendidikan bagi warga negara diatur dalam Undang-Undang Nomor 32 tahun 2004 tentang pemerintahan daerah. Ternyata, pemenuhan hak atas pendidikan bukan hanya tanggungjawab pemerintah pusat saja, tetapi juga menjadi tanggungjawab pemerintah daerah (provinsi dan kabupaten/kota). ${ }^{10}$ Untuk itu, pemerintah daerah juga seharusnya membuat peraturan daerah (Perda) yang secara khusus mengatur tentang pendidikan. Hal ini terkait dengan undangundang yang menyatakan bahwa "... minimal 20\% dari Anggaran Pendapatan dan Belanja Daerah (APBD)".

Pasca terbitnya UU Nomor 32 Tahun 2004 ditemukan fakta bahwa hanya empat daerah yang secara khusus telah mengeluarkan Perda yang mengatur tentang pendidikan yaitu Nangro Aceh Darussalam (NAD), DKI, Gorontalo dan Papua. ${ }^{11}$ Dalam hal pembiayaan pendidikan, hanya Perda Provinsi Papua yang secara tegas dan jelas menyebutkan prosentase alokasi dana untuk pembiayaan pendidikan sebesar $30 \%$ dari penerimaan dalam rangka otonomi khusus, dana bagi hasil $(\mathrm{DBH})$ sumber daya alam pertambangan minyak bumi, dan DBH gas alam yang peruntukannya di luar penyelenggaraan pendidikan kedinasan. Sedangkan provinsi lain tidak menyebutkan prosentase dana secara jelas. 
Penyebutan prosentase anggaran pendidikan dalam Perda dinilai sangat penting sebab sebagai acuan, kontrol dan bukti komitmen pemerintah daerah terhadap pemenuhan hak atas pendidikan dan perbaikan pendidikan nasional.

\section{Masalah Pemerataan dan Akses Pendidikan}

Pemerataan dan perluasan akses pendidikan menjadi masalah penting dalam upaya pemenuhan hak atas pendidikan. Hal ini mencakup perluasan daya tampung satuan pendidikan serta memberikan kesempatan yang sama bagi semua peserta didik dari berbagai golongan masyarakat yang berbeda baik secara sosial, ekonomi, gender, lokasi tempat tinggal dan tingkat kemampuan intelektual serta kondisi fisik. Pemerataan pendidikan adalah pemberian kesempatan yang sama bagi semua warga negara atas dasar dan prinsip nondiskriminatif. Artinya, setiap warga masyarakat, tanpa memandang ras, warna kulit, kecacatan, jenis kelamin, kelas sosial atau bentuk-bentuk stratifikasi sosial lainnya, berhak untuk diberi kesempatan yang sama dalam memasuki suatu program pendidikan.

Akses pendidikan adalah kemudahan yang diberikan kepada setiap warga masyarakat untuk menggunakan kesempatannya memasuki suatu program pendidikan. Akses tersebut dapat berupa sikap sosial yang nondiskriminatif, kebijakan politik dalam bentuk peraturan perundang-undangan yang mendukung dan mencegah diskriminasi, tersedianya lingkungan fisik pendidikan yang aksesibel, tersedianya alat bantu belajar/mengajar yang sesuai, dan biaya pendidikan yang terjangkau, yang memungkinkan setiap warga masyarakat menggunakan kesempatannya untuk mengikuti proses belajar/mengajar di program pendidikan yang dipilihnya. Kesempatan dan akses adalah dua hal yang saling terkait dan saling menentukan.

Pemerataan dan perluasan akses pendidikan dapat dilihat dengan indikator jumlah Angka Masukan Kasar (AMK), Angka Melanjutkan (AM), Angka Partisipasi Kasar (APK), Angka Partisipasi Murni (APM), Angka Partisipasi Murni Usia Sekolah (APMUS), Rasio Pendidikan, Tingkat Pelayanan Sekolah (TPS), Perkembangan Angka Melanjutkan dan Tidak Melanjutkan, dan Perkembangan APK, APM dan APMUS.

Data pendidikan menunjukkan bahwa penduduk usia 0-18 tahun berjumlah 80.519.057. Dari jumlah ini yang mendapatkan layanan pendidikan atau bersekolah berjumlah 50.954.358, sedangkan yang tidak/belum mendapatkan layanan pendidikan atau bersekolah berjumlah 29.564.699. Angka putus sekolah pada Sekolah Dasar (SD/MI) berjumlah 486.426 (1,63\%), pada Sekolah Menengah Pertama (SMP/MTs) berjumlah 255.210 (2,22\%), dan pada Sekolah Menengah Atas (SMA/MA) berjumlah 167.838 (2,33\%). Angka lulusan tidak melanjutkan pada Sekolah Dasar (SD/MI) berjumlah 431.937 (10,54\%), pada Sekolah Menengah Pertama (SMP/MTs) berjumlah 412.135 (13,66\%), dan pada Sekolah Menengah Atas (SMA/MA) berjumlah 678.010 (35,65\%).12 Indikator pemerataan dan perluasan akses pendidikan dapat dilihat pada tebel berikut: 
Tabel 2. Indikator Pemerataan dan Perluasan Akses Pendidikan

\begin{tabular}{|c|c|c|c|c|c|}
\hline No & \multicolumn{5}{|c|}{ Variabel/Indikator } \\
\hline $\mathrm{I}$ & \multicolumn{5}{|c|}{$\begin{array}{l}\text { Penduduk Usia Sekolah, Bersekolah, Tidak/Belum Bersekolah, Putus Sekolah dan } \\
\text { Lulusan Tidak Melanjutkan }\end{array}$} \\
\hline & Penduduk Usia Sekolah & Penduduk & Bersekolah & $\begin{array}{l}\text { tidak/belum } \\
\text { bersekolah }\end{array}$ & \\
\hline & $0-6$ tahun & 28.426 .505 & 6.594 .086 & 21.832 .419 & \\
\hline & $7-12$ tahun & 26.304 .320 & 26.015 .842 & 288.478 & \\
\hline & 13-15 tahun & 12.890 .334 & 11.019 .242 & 1.871 .092 & \\
\hline & 16-18 tahun & 12.897 .898 & 7.325 .188 & 5.572 .710 & \\
\hline & e. 19-24 tahun & 25.077 .900 & 4.325 .354 & 20.752 .546 & \\
\hline & Jumlah 0-18 tahun & 80.519 .057 & 50.954 .358 & 29.564 .699 & \\
\hline & Putus Sekolah & $\mathrm{SD}+\mathrm{MI}$ & $\mathrm{SMP}+\mathrm{MTs}$ & $\mathrm{SM}+\mathrm{MA}$ & \\
\hline & Jumlah & 486.426 & 255.21 & 167.838 & \\
\hline & Persentase & 1,63 & 2,22 & 2,33 & \\
\hline & Lulusan Tidak Melanjutkan & $\mathrm{SD}+\mathrm{MI}$ & $\mathrm{SMP}+\mathrm{MTs}$ & $\mathrm{SM}+\mathrm{MA}$ & \\
\hline & Jumlah & 431.937 & 412.135 & 678.01 & \\
\hline & Persentase & 10,54 & 13,66 & 35,65 & \\
\hline II & \multicolumn{5}{|c|}{ Angka Masukan Kasar (AMK) SD/MI Menurut Jenis Kelamin } \\
\hline & Jenis Kelamin & \begin{tabular}{ll}
\multicolumn{2}{l}{ Penduduk } \\
usia \\
tahun
\end{tabular} & $\begin{array}{l}\text { Siswa baru } \\
\text { tingkat I }\end{array}$ & AMK \% & \\
\hline & Laki-laki & 2.036 .000 & 2.622 .412 & 128,80 & \\
\hline & Perempuan & 1.966 .200 & 2.476 .996 & 125,98 & \\
\hline & Jumlah & 4.002 .200 & 5.099 .408 & 127,42 & \\
\hline \multirow[t]{5}{*}{ III } & $\begin{array}{l}\text { Angka Melanjutkan (AM) } \\
\text { menurut Jenjang Pendidikan }\end{array}$ & & & & \\
\hline & Jenjang Pendidikan & Lulusan & $\begin{array}{l}\text { Siswa Baru } \\
\text { Yk.I/Mhs } \\
\text { Baru } \\
\end{array}$ & $\mathrm{AM} \%$ & \\
\hline & AM ke SMP & 4.097 .297 & 3.665 .360 & 89,46 & \\
\hline & AM ke SM & 3.018 .143 & 2.606 .008 & 86,34 & \\
\hline & $\mathrm{AM} \mathrm{ke} \mathrm{PT}^{*}$ & 1.902 .108 & 1.224 .098 & 64,35 & \\
\hline IV & \multicolumn{5}{|l|}{ Angka Partisipasi Kasar (APK) } \\
\hline & Jenjang Pendidikan & $\begin{array}{l}\text { Kelompok } \\
\text { Usia }\end{array}$ & $\begin{array}{l}\text { Penduduk } \\
\text { Usia } \\
\text { Sekolah } \\
\end{array}$ & Siswa/Mhs & $\begin{array}{l}\text { APK } \\
\%\end{array}$ \\
\hline & PAUD & $0-6$ tahun & 29847830 & 7.804 .134 & 60,51 \\
\hline & $\mathrm{TK}+\mathrm{RA}$ & 4-6 tahun & 10.076 .448 & 15.109 .682 & 50,62 \\
\hline & SD+MI+Paket A & $7-12$ tahun & 26.304 .320 & 3.584 .338 & 35,57 \\
\hline & $\mathrm{SMP}+\mathrm{MTs}+$ Paket B & $\begin{array}{l}13-15 \\
\text { tahun }\end{array}$ & 12.890 .334 & 30.384 .766 & $\begin{array}{l}115,5 \\
1\end{array}$ \\
\hline & $\mathrm{SM}+\mathrm{MA}+$ Paket C & $16-18$ & 12.897 .898 & 11.900 .783 & 92,32 \\
\hline
\end{tabular}




\begin{tabular}{|c|c|c|c|c|c|}
\hline No & \multicolumn{5}{|c|}{ Variabel/Indikator } \\
\hline I & \multicolumn{5}{|c|}{$\begin{array}{l}\text { Penduduk Usia Sekolah, Bersekolah, Tidak/Belum Bersekolah, Putus Sekolah dan } \\
\text { Lulusan Tidak Melanjutkan }\end{array}$} \\
\hline & & tahun & & & \\
\hline & PT+PTAI+PTK & $\begin{array}{l}19-24 \\
\text { tahun }\end{array}$ & 25.077 .900 & 4.325 .354 & 17,25 \\
\hline $\mathrm{V}$ & \multicolumn{5}{|c|}{ Angka Partisipasi Murni (APM) } \\
\hline & Jenjang Pendidikan & $\begin{array}{l}\text { Kelompok } \\
\text { Usia }\end{array}$ & $\begin{array}{l}\text { Penduduk } \\
\text { Usia } \\
\text { Sekolah } \\
\end{array}$ & $\begin{array}{l}\text { Siswa Usia } \\
\text { sekolah }\end{array}$ & $\begin{array}{l}\text { APM } \\
\%\end{array}$ \\
\hline & $\mathrm{TK}+\mathrm{RA}$ & 4-6 tahun & 10.076 .448 & 2.412 .177 & 23,94 \\
\hline & $\mathrm{SD}+\mathrm{MI}$ & $7-12$ tahun & 26.304 .320 & 24.964 .102 & 94,90 \\
\hline & $\mathrm{SMP}+\mathrm{MTs}$ & $\begin{array}{l}13-15 \\
\text { tahun }\end{array}$ & 12.890 .334 & 9.229 .945 & 71,60 \\
\hline & $\mathrm{SM}+\mathrm{MA}$ & $\begin{array}{l}16-18 \\
\text { tahun }\end{array}$ & 12.897 .898 & 6.473 .906 & 50,19 \\
\hline VI & \multicolumn{5}{|c|}{ Angka Partisipasi Murni Usia Sekolah (APMus) } \\
\hline & Kelompok Usia & $\begin{array}{l}\text { Penduduk } \\
\text { Usia } \\
\text { Sekolah } \\
\end{array}$ & $\begin{array}{l}\text { Siswa Usia } \\
\text { sekolah }\end{array}$ & APM \% & \\
\hline & 4-6 tahun & 10.076 .448 & 11.019 .242 & 85,48 & \\
\hline & $7-12$ tahun & 26.304 .320 & 6.594 .086 & 65,44 & \\
\hline & 13-15 tahun & 12.890 .334 & 26.015 .842 & 98,90 & \\
\hline & 16-18 tahun & 12.897 .898 & 7.325 .188 & 56,79 & \\
\hline
\end{tabular}

*diolah dari berbagai sumber dan Balitbang Kemendikbud 2008

Melihat keadaan yang ditunjukkan pada tabel di atas, permintaan masyarakat akan kesempatan pendidikan terus meningkat. Pemerintah harus dapat melayani dan memenuhi permintaan tersebut. Pemerataan dalam pendidikan adalah salah satu indikator penting yang harus dicapai dalam rangka mencapai keadilan dan pemenuhan hak atas pendidikan. Tabel berikut menunjukkan indeks pemerataan APK (equality index) antara APK di kabupaten sebagai proksi daerah pedesaan dan APK di kota sebagai proksi di daerah perkotaan. Semakin kecil nilai indeks pemerataan ini semakin baik karena pelayanan pendidikan semakin merata. Angka ideal dari indeks pemerataan adalah $0 \%$ yang menunjukkan tidak ada perbedaan dalam kesempatan pendidikan antara daerah pedesaan dengan daerah perkotaan. ${ }^{13}$

Tabel 3. Angka Ideal Indeks Pemerataan Pendidikan

\begin{tabular}{|l|l|c|c|c|c|c|c|}
\hline No & Indikator Kunci Kinerja & 2004 & 2005 & 2006 & 2007 & 2008 & 2009 \\
\hline 1 & $\begin{array}{l}\text { Disparitas APK PAUD antara } \\
\text { Kabupaten dan Kota }\end{array}$ & $6,04 \%$ & $5,42 \%$ & $4,37 \%$ & $4,20 \%$ & $3,61 \%$ & $3,02 \%$ \\
\hline 2 & $\begin{array}{l}\text { Disparitas APK } \\
\text { SD/MI/SDLB Paket A } \\
\text { antara Kabupaten dan Kota }\end{array}$ & $2,49 \%$ & $2,49 \%$ & $2,43 \%$ & $2,40 \%$ & $2,28 \%$ & $2,00 \%$ \\
\hline
\end{tabular}




\begin{tabular}{|l|l|l|c|c|c|c|c|}
\hline 3 & $\begin{array}{l}\text { Disparitas APK SMP/MTs/ } \\
\text { PAket B antara Kabupaten } \\
\text { dan Kota }\end{array}$ & $25,14 \%$ & $\begin{array}{c}25,14 \\
\%\end{array}$ & $\begin{array}{c}23,44 \\
\%\end{array}$ & $23,00 \%$ & $\begin{array}{c}20,18 \\
\%\end{array}$ & $13,00 \%$ \\
\hline 4 & $\begin{array}{l}\text { Disparitas APK } \\
\text { SMA/MA/SMK/SMALB } \\
\text { paket C antara Kabupaten dan } \\
\text { Kota }\end{array}$ & $33,13 \%$ & $\begin{array}{c}33,13 \\
\%\end{array}$ & $\begin{array}{c}31,44 \\
\%\end{array}$ & $31,20 \%$ & $\begin{array}{c}29,97 \\
\%\end{array}$ & $55,00 \%$ \\
\hline 5 & $\begin{array}{l}\text { Disparitas gender APK di } \\
\text { jenjang pendidikan menengah }\end{array}$ & $6,16 \%$ & $6,07 \%$ & $5,50 \%$ & $5,45 \%$ & $4,45 \%$ & $5,71 \%$ \\
\hline 6 & $\begin{array}{l}\text { Disparitas gender APK di } \\
\text { jenjang pendidikan Tinggi }\end{array}$ & $9,90 \%$ & $9,62 \%$ & $0,17 \%$ & $0,59 \%$ & $2,28 \%$ & $8,48 \%$ \\
\hline 7 & $\begin{array}{l}\text { Disparitas gender persentase } \\
\text { Buta Aksara }\end{array}$ & $7.32 \%$ & $6,59 \%$ & $5,33 \%$ & $5,09 \%$ & $3,24 \%$ & $3,65 \%$ \\
\hline
\end{tabular}

Tabel di atas menunjukkan bahwa pada tahun 2004 indeks pemerataan APK PAUD masih sekitar 6\% dan semakin mengecil setiap tahunnya, dan diperkirakan akan terus merata pada tahun-tahun berikutnya. Indeks pemerataan APK-SD/MI cukup rendah sejak tahun 2004 (2,49\%) karena keberhasilan dalam perluasan SD sudah dicapai sejak tahun 1990. Indeks pemerataan antara APKSMP/MTs mencapai 13\%. Angka ini sesungguhnya masih cukup tinggi karerna kesempatan belajar di SMP masih dalam proses perluasan dalam rangka pelaksanaan program Wajardikdas 9 tahun. Perluasan SMP di perkotaan jauh lebih maju dibandingkan dengan di pedesaan karena pemerintah kota lebih mampu mengalokasikan anggaran ke sektor pendidikan.

Indeks pemerataan APK-SMA/MA/SMK sederajat masih menghadapi persoalan yang serius. Pada tahun 2004 kesempatan pendidikan menengah masih sangat tidak merata, antara penduduk di daerah perkotaan dan daerah pedesaan. Hal ini ditunjukkan dengan indeks pemerataan 33\%. Empat tahun berikutnya yaitu pada tahun 2008 indeks pemerataan hanya menunjukkan 3\% penurunan yang kurang signifikan untuk pemerataan.

Aspek gender juga memperlihatkan disparitas APK yang cukup tinggi. Khususnya pada pendidikan menengah, pendidikan tinggi dan angka buta aksara. Pada tahun 2004 indeks pemerataan berdasarkan gender sebesar 5\%, dan 7\% indeks pemerataan angka buta aksara. Indeks paritas angka buta huruf antara laki-laki dan perempuan berhasil ditekan dan secara konsisten menurun hingga mencapai 3,2\% pada tahun 2008 .

Melihat hal tersebut di atas, dalam rangka pemenuhan hak atas pendidikan sebagaimana amanat konstitusi maka dilakukan strategi program prioritas dalam rangka upaya pemerataan dan perluasan akses pendidikan, peningkatan mutu, relevansi, daya saing keluaran pendidikan, peningkatan tata kelola, akuntabilitas, dan citra publik pengelolaan pendidikan.

\section{Islam Memandang Hak Asasi Pendidikan}

Sebagai agama kemanusiaan (religious of humanity), ajaran Islam mencakup dan melingkupi semua aspek hidup dan perikehidupan. Islam, sejak awal kelahirannya telah mengajarkan dan mengapresiasi prinsip-prinsip hak asasi 
manusia (HAM). Penghormatan dan penghargaan terhadap manusia dan kemanusiaan menjadi ajaran pokok dan penting di dalam Islam. Di antara ajaran pokok tersebut adalah tentang tata cara yang mesti dilakukan manusia dalam berilmu, beramal dan menjalin hubungan (ta'aruf) dengan sesama manusia dan seluruh makhluk Tuhan lainnya.

Dalam konteks hak asasi pendidikan, ajaran Islam sangat menaruh perhatian terhadap umatnya yang menuntut ilmu pengetahuan. Banyak ayat-ayat al-Qur'an dan hadis yang menganjurkan setiap orang untuk berilmu. Bahkan hukum menuntut ilmu atau Thalabul 'Ilmi itu wajib bagi setiap manusia. Kewajiban tersebut menunjukkan bahwa ada hak yang sama bagi umat manusia, baik laki-laki, perempuan, anak-anak maupun dewasa dalam memperoleh pendidikan. Beberapa hadis nabi yang berhubungan dengan hak asasi pendidikan diantaranya;

"Mencari ilmu itu wajib atas setiap muslim baik laki-laki maupun perempuan"; 14

"Tuntutlah ilmu walau ke negeri Cina";

"Menuntut ilmu dilakukan sejake dari ayunan hingga ke liang lahat";

"Barang siapa meniti satu jalan untuk mencari ilmu, niscaya Allab akan memudabkan jalan ke sorga";

"Sesunggubnya keutamaan seorang 'alim atas abli ibadab seperti keutamaan bulan purnama daripada selurub bintang-bintang";

"Sesunggubnya para ulama itu pewaris para Nabi; 15 "Satu orang abli ilmu lebih utama dibandingkean seribu abli badah".

Beragam hadis di atas menunjukkan bahwa Islam tidak hanya sebatas mewajibkan saja kepada umatnya untuk menuntut ilmu dan pendidikan, akan tetapi Islam juga mengajarkan bahwa seyogyanya kaum muslim, dalam menuntut ilmu dan pendidikan, tidak memilah-milah ilmu dan lembaga pendidikan. Tidak ada dikotomi ilmu di dalam Islam. Di dalam Islam, semua ilmu itu pada dasarnya sama yakni berasal dari dan kepunyaan Allah. Tidak ada perbedaan antara ilmu umum dengan ilmu agama. Semuanya wajib dipelajari dan dicari serta diamalkan untuk kemaslahatan diri dan masyarakat luas.

Al-Qur'an banyak menegaskan dan menekankan tentang keutamaan dan keharusan seseorang untuk meraih ilmu pengetahuan dan menempuh pendidikan diantaranya:

"Hai orang-orang yang beriman, apabila dikatakan kepadamu: 'Berlapang-lapanglah dalam majelis, maka lapangkanlah, niscaya Allah akan memberi kelapangan untukmu. Dan apabila dikatakan:' Berdirilah kamu, maka berdirilah, niscaya Allah akan meninggikan orang-orang yang beriman di antaramu dan orang-orang 
yang diberi ilmu pengetabuan beberapa derajat. Dan Allab Maba Mengetabui apa yang kamu kerjakan". ${ }^{16}$

Apakah sama orang-orang yang mengetahui dengan orang-orang yang tidak mengetahui? Sebenarnya hanya orang yang berakal sehat yang dapat menerima pelajaran". ${ }^{17}$

"Maka tanyakanlah olehmu kepada orang-orang yang berilmu, jika kamu tiada mengetahui". 18

"Allah akan mengangkat orang-orang yang beriman dan diberikan ilmu di antara kalian beberapa derajat. Allah Maha mengetabui apa yang kalian kerjakan". ${ }^{19}$

"Tidak sepatutnya bagi orang-orang yang mu'min itu pergi semuanya (ke medan perang). Mengapa tidak pergi dari tiap-tiap golongan di antara mereka beberapa orang untuk memperdalam tentang agama dan untuk memberi peringatan kepada kaumnya apabila mereka telab kembali kepadanya, supaya mereka itu dapat menjaga dirinya”. ${ }^{20}$

"Barang siapa yang beramal shaleh (laki-laki dan perempuan), dan mereka adalah orang yang beriman, baginya kehidupan yang baik.". 21

Dalil-dalil di atas menunjukkan bahwa kewajiban dan hak mempunyai ilmu (pengetahuan) tidak hanya pada diri lelaki, tetapi juga perempuan. Allah tidak membedakan bangsa, jenis, suku, ras, dan kedudukan sosial manusia dalam hal memberikan pahala atas amal kebajikan yang diperbuat oleh hamba-Nya, termasuk dalam perkara menuntut ilmu dan pendidikan. Allah juga berjanji akan memuliakan seseorang atau suatu bangsa yang dilimpahi dengan penguasaan ilmu pengetahuan dan teknologi. Bangsa yang berilmu adalah bangsa yang umumnya berperadaban tinggi. Bangsa Arab pernah meraih predikat sebagai bangsa yang berperadaban tinggi karena mereka menguasai ilmu pengetahuan dan teknologi.

Hubungannya dengan hak asasi pendidikan adalah, bahwa dalam hukum Islam, sebagai upaya penegakan syariat Islam, dikenal lima hak (al-Hukuq alKhomsah/al-Kuliah al-Khomsah). Lima hak ini seyogyanya mendapatkan perhatian yang serius sehingga umat Islam dapat mewujudkan syariah yang baik (maqoshid al-Syariah). Kelima hak tersebut adalah bifdz al-nafs (menjamin kelangsungan hidup), hifdz al-aql (menjamin kebebasan berfikir, beropini, dan berkespresi), hifdz. ad-din (menjamin kebebasan beragama), bifdz an-nasl (menjamin hak kelangsungan hidup manusia), dan hifdz al-maal (menjamin hak property atau kekayaan berupa hak mendapatkan pekerjaan, upah yang layak, jaminan perlindungan dan kesejahteraan).

Hak untuk mendapatkan perlindungan terhadap akal (Hifdz al-aql) sangat berhubungan dengan hak mendapatkan pendidikan atau berpendidikan sebagai dasar untuk menjaga akal. Jika larangan meminum khamr dan semua minuman yang memabukkan dapat disyariatkan sebagai upaya untuk menjaga akal, maka 
mengembangkan fungsi akal melalui pendidikan, penyediaan bahan bacaan, penelitian dan berbagai bentuk kegiatan yang dapat mengoptimalkan fungsi akal dapat disyariatkan pula oleh manusia sebagai upaya untuk memenuhi hak dan kewajiban memperoleh pendidikan yang layak.

Hak berpendidikan berarti bahwa setiap orang di dunia ini berhak mendapatkan ilmu pengetahuan sesuai dengan kemampuannya. Negara atau pemerintah (daulah) sebagai pengemban amanat publik (ummat) tidak boleh melarang atau menghalangi seseorang untuk mendapatkan ilmu pengetahuan. Sebaliknya, pemerintah wajib menyediakan, memfasilitasi dan menjamin setiap warga negara mendapatkan pendidikan yang layak, bermutu, tanpa diskriminasi. Dengan cara ini, arah maqashid syariah telah dirubah dan dikembangkan dari sekedar menjaga struktur akal (bifdz al-aql) kepada mengoptimalkan fungsi akal tersebut. $^{22}$

Praktik hak dan kewajiban pemenuhan terhadap pendidikan bagi umat manusia sesungguhnya telah tersirat dalam kehidupan Rasulullah yang dituangkan dalam Piagam Madinah. Piagam tersebut pada intinya menggarisbawahi lima hal pokok sebagai dasar bagi kehidupan bermasyarakat dan bernegara. Pertama, prinsip persaudaraan yang menegaskan bahwa semua manusia berasal dari satu asal oleh karenanya mereka bersaudara. Kedua prinsip saling menolong dan melindungi penduduk Madinah yang terdiri dari berbagai macam suku, agama, dan bahasa harus saling membantu dalam menghadapi lawan. Ketiga, prinsip melindungi yang lemah dan teraniaya. Keempat, prinsip saling menasehati, dan kelima prinsip kebebasan beragama. ${ }^{23}$

Prinsip-prinsip pokok yang tertuang dalam Piagam Madinah tersebut merefleksikan beberapa ajaran Islam yakni; tidak ada paksaan dalam beragama ${ }^{24}$, pengakuan terhadap kebebasan dan keberagaman dalam keberagamaan (pluralisme) ${ }^{25}$, larangan memaksa-maksa orang memeluk Islam ${ }^{26}$, himbauan kepada ahli kitab untuk mencari titik temu dan mencapai kalimatun sawa ${ }^{27}$, anjuran berbuat baik, berlaku adil, dan menolong kepada non-Muslim yang tidak memusuhi dan tidak mengusir mereka ${ }^{28}$.

Ketercapaian kehidupan umat yang madani yang ditekankan oleh Rasullullah pada saat itu tidak mungkin dapat tercapai jika tidak mempunyai ilmu pengetahuan, yaitu dengan memfungsikan dan mengoptimalkan potensi akal melalui pendidikan. Prinsip atau himbauan Rasullullah untuk mencari titik temu dan mencapai kalimatun sawa, anjuran berbuat baik, dan berlaku adil tidak mungkin dapat tercapai jika tidak dibekali dengan ilmu pengetahuan. Oleh karena, dalam rangka mencapai masyarakat madani itu harus menggunakan instrumen ilmu pengetahuan yang dikuasai umat, maka mendapatkan pendidikan sebagai sarana mendapatkan ilmu pengetahuan itu menjadi wajib adanya. Dengan kata lain, pendidikan merupakan hak asasi bagi semua umat, dan negara atau daulah berkewajiban memberikannya sebagai jalan mencapai tujuan pemerintahan yaitu masyarakat yang damai, adil, sejahtera, dan berbudaya (madany). 


\section{SIMPULAN}

Hak mendapatkan layanan pendidikan dijamin oleh Undang-Undang Dasar dan berbagai instrumen perundang-undangan internasional lainnya namun dalam pelaksanaannya masih mengalami beberapa problem. Masalah tersebut meliputi masalah legislasi dan kebijakan, masalah anggaran pendidikan, masalah pemerataan dan akses pendidikan yang mencakup kesetaraan gender dalam memperoleh pendidikan dan akses pendidikan di wilayah konflik, perbatasan dan terpencil.

Masalah-masalah legislasi dan kebijakan berhubungan dengan keadaan bahwa belum sepenuhnya selaras antara undang-undang dan kebijakan pendidikan nasional dengan cita-cita luhur kemerdekaan serta konstitusi UUD 1945. Instrumen-instrumen dan standar HAM nasional belum berbasis atas hak asasi manusia yang dituntut oleh kovenan-kovenan internasional sehingga berdampak pada upaya pemerataan pendidikan di Indonesia masih terkesan terabaikan.

Masalah anggaran pendidikan berkenaan dengan komitmen pemerintah untuk menganggarkan sektor pendidikan sesuai dengan amanat UUD 1945 dan UUSPN Nomor 20 Tahun 2003 sebesar sekurang-kurangnya 20\% dari APBN dan APBD mestinya di luar gaji pendidik dan biaya pendidikan rutin dan kedinasan.

Masalah pemerataan dan akses pendidikan mencakup perluasan daya tampung satuan pendidikan serta memberikan kesempatan yang sama bagi semua peserta didik dari berbagai golongan masyarakat yang berbeda baik secara sosial, ekonomi, gender, lokasi tempat tinggal dan tingkat kemampuan intelektual serta kondisi fisik.

Islam sebagai agama yang dianut oleh mayoritas penduduk Indonesia diharapkan memberikan pandangan bahkan solusi yang tidak hanya pada tahap wacana namun juga praksis. Dalam perspektif Islam, negara (daulab) baik secara politis, hukum, ekonomi maupun budaya "haram" menghalangi warganya untuk menuntut ilmu dan memperoleh kesempatan pendidikan. Berarti pemerintah "wajib" (jika tidak maka berdosa) menyelenggarakan pendidikan yang semurah mungkin dan sebaik mungkin untuk rakyatnya.

\section{DAFTAR PUSTAKA}

Ábdillah, Abi, Muhammad Bin Yazid, 1987, Sunan Ibn Majah, t.: Dar Ihya' alKutub Al-Árabiyyah.

Al-Qur'an, Terjemahan Kementerian Agama RI

An-Nasaí, Abdurrahman,1986, Sunan an-Nasaí, Halib: Maktab al-Matbu'ah alIslamiyah.

At-Turmuzdi, 1983, Sunan at-Turmudzi, t.: al-Maktab al-Islamiyah,

Dawud, Abi, t.th. Sunan Abi Dawnd, Turki-Istanbul: al-Maktabah al-Islamiyah li Tabaáh. 
Esposito, John L., 1995, The Oxford Encyclopedia of the Modern Islamic Word, dalam entri Legal Thought and Jurisprudence, Oxford: Oxford University Press,

Komnas HAM, 2009, Komentar Umum Kovenan Internasional Hak Sipil dan Politik Kovenan Internasional Hak Ekonomi Sosial dan Budaya, Jakarta: Komnas HAM.

Komnas HAM, 2005, Pendidikan Untuk Semua, Advokasi terhadap Kebijakan Pendidikan Nasional, Jakarta: Komnas HAM.

Konvensi Hak Anak,1989, (Convention on the Rights of the Child).

Kovenan Internasional Hak Sipil dan Politik (International Covenant on Civil and Political Rights), 1966.

Machali, Imam Kebijakan Pembiayaan Pendidikan dalam Peraturan Daerab; Studi Perda tentang Pendidikan di lima Propinsi, dalam Jurnal At-Tarbawi, 2009, STAIN Surakarta Vol. 7 No. 2 November 2008 - April

Muslim, Al-Imam, Bin Hajjaj an-Nisabury, 1985, Sabib al-Muslim, Bairut: Dar Ihya' Kutub al-Árabiyah.

Muhammad ibn Idris Asyafi'i, tt, al Umm, Bairut-Lebanon:Dar Ma'rifah.

Musdah Mulia, 2010, Islam dan Hak Asasi Manusia, Konsep dan Implementasi, Yogyakarta: Naufan Pustaka.

Peraturan Daerah Istimewa Yogyakarta (Perda Diy) Nomor 14 Tahun 1954 (14/1954) Tentang Pelaksanaan penyerahan sebagian dari urusan Pemerintah Daerah Istimewa Yogyakarta dalam lapangan pendidikan, pengajaran dan kebudayaan kepada Daerah-daerah Otonom Kabupaten dalam Daerah Istimewa Yogyakarta

Peraturan Daerah Nomor 5 Tahun 2006 Tentang Pembangunan Pendidikan di Provinsi Papua.

Peraturan Daerah Propinsi Daerah Istimewa Aceh Nomor 6 Tahun 2000 Tentang Penyelenggaraan Pendidikan.

Peraturan Daerah Provinsi Daerah Khusus Ibukota Jakarta Nomor 8 Tahun 2006 Tentang Sistem Pendidikan.

Peraturan Daerah Provinsi Gorontalo Nomor 06 Tahun 2005 tentang Pendidikan Berbasis Kawasan.

Peraturan Pemerintah nomor 48 tahun 2008 tentang Pendanaan pendidikan.

Suryadi, Ace dan Budiansyah, Dasim, 2009, Paradigma Pembangunan Pendidikan

Nasional, Bandung: Widya Aksara Press.

Undang-Undang Nomor 39 Tahun 1999 tentang HAM.

Undang-Undang Dasar 1945.

Undang-Undang Nomor 26 Tahun 2000 tentang Pengadilan HAM.

Undang-Undang Nomor 32 tahun 2004 Tentang Pemerintah Daerah.

Undang-Undang Nomor 20 Tahun 2003 tentang Sistem Pendidikan Nasional.

www.hidayatullah.com "Antara-maqashid-syariah-dan-karakter-umat" diakses pada 2

Februari 2012.

Zahro, Abu,1973, Ushul Fiqh, Mesir: Dar Fikr al Arabi. 
${ }^{1}$ Komnas HAM, Komentar Umum Kovenan Internasional hak Sipil dan Politik Kovenan Internasional Hak Ekonomi Sosial dan Budaya (Jakarta: Komnas HAM, 2009) hal, ix.

2Pasal 1 angka 1 UU Nomor 39 Tahun 1999 tentang HAM dan UU No. 26 Tahun 2000 tentang Pengadilan HAM

${ }^{3}$ Kovenan Internasional Hak Sipil dan Politik (International Covenant on Civil and Political Rights) tahun 1966, Pasal 28 ayat 4

${ }^{4}$ Konvensi Hak Anak (Convention on the Rights of the Child) tahun 1989 pasal 28

${ }^{5}$ UU nomor 20 Tahun 2003 tentang Sistem Pendidikan Nasional

${ }^{6}$ Pemerintah dan pemerintah daerah.......

${ }^{7}$ Komnas HAM, Pendidikan Untuk Semua,... 63

8 Dampak dari rendahnya anggaran pendidikan ini adalah semakin sempitnya kesempatan belajar bagi anak-anak dari keluarga miskin dan terpinggirkan karena tidak mampu membiayai pendidikan putra-putri mereka. Rendahnya anggaran pendidikan ini juga mempengaruhi tingkat profesionalisme guru dan ketersediaan infrastruktur pendidikan dan fasilitas belajar. Anggaran pendidikan 20 persen sebenarnya masih jauh dari target kesepakatan yang dihasilkan dalam KTT (Konfrensi Tingkat tinggi) tentang pendidikan (1992) minimal 25\% dari APBN.

${ }^{9}$ Mahkamah Konstitusi menyatakan agar memasukkan komponen gaji pendidik dalam perhitungan anggaran pendidikan, menurut Mahkamah Konstitusi, lebih mudah bagi Pemerintah bersama DPR untuk melaksanakan kewajiban memenuhi anggaran pendidikan sekurang-kurangnya $20 \%$ dalam APBN.

${ }^{10}$ UU nomor 32 tahun 2004 pasal 14 dan 15

11 DIY jauh sebelum UUSPN No. 20 tahun 2003 dan UU No 32 tahun 2004 telah mengeluarkan perda nomor 14 tahun 1954 tentang pelaksanaan penyerahan sebagian dari urusan pemerintah daerah Istimewa Yogyakarta dalam lapangan pendidikan, pengajaran, dan kebudayaan kepada daerah-daerah otonom kebupaten dalam Daerah Istimewa Yogyakarta. Lihat: Imam Machali, Kebijakan Pembiayaan Pendidikan dalam Peraturan Daerab; Studi Perda tentang Pendidikan di lima Propinsi, dalam Jurnal At-Tarbawi, STAIN Surakarta Vol. 7 No. 2 November 2008 - April 2009 hal. 161

${ }^{12}$ Data yang dilansir Balitbang Kementerian Pendidikan Nasional pada tahun 2008

13 Ace Suryadi, Dasim Budiansyah, Paradigma Pembangunan Pendidikan Nasional, (Bandung: Widya Aksara Press, 2009), hal. 135-136

${ }^{14} \mathrm{HR}$. Ibnu Majah, no:224, dishahihkan oleh Syeikh Al-Albani di dalam Shahih Ibni Majah.

${ }^{15}$ HR. Abu Dawud no:3641, Tirmidzi no:3641; Ibnu Majah no: 223; Ahmad 4/196; Darimi no: 1/98. Dihasankan Syeikh Salim Al-Hilali di dalam Bahjatun Nazhirin 2/470, hadits no: 1388

${ }^{16}$ QS. Al-Mujadilah 58:11

${ }^{17}$ QS. Az Zumar [39]: 9

${ }^{18}$ QS. Al Anbiya' [21]:7

${ }^{19}$ QS. Al Mujadilah [58]: 11

${ }^{20}$ QS. At-Taubah [9]: 122

${ }^{21}$ QS. Ali Imron [3]:27

${ }^{22}$ www.hidayatullah.com "Antara-maqashid-syariah-dan-karakter-umat" diakses pada 2 Februari

2012

23 Musdah Mulia, Islam dan Hak Asasi Manusia, Konsep dan Implementasi, (Yogyakarta: Naufan Pustaka, 2010), hal. 10

${ }^{24}$ Q.S. al-Baqoroh [2]:256

${ }^{25}$ Q.S. al-Kafirun [109]:1-6

${ }^{26}$ Q.S. Yunus [10]:99

${ }^{27}$ Q.S. Ali Imron [3]:64

${ }^{28}$ Q.S. al-Mumtahanah [60]: 8-9 